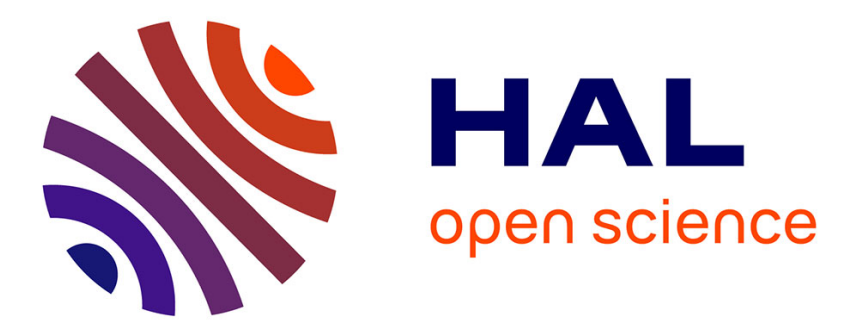

\title{
Nematode community dynamics over an annual production cycle in the central North Sea
}

\author{
M. Schratzberger, R.M. Forster, F. Goodsir, S. Jennings
}

\section{To cite this version:}

M. Schratzberger, R.M. Forster, F. Goodsir, S. Jennings. Nematode community dynamics over an annual production cycle in the central North Sea. Marine Environmental Research, 2008, 66 (5), pp.508. 10.1016/j.marenvres.2008.08.004 . hal-00501980

\section{HAL Id: hal-00501980 \\ https://hal.science/hal-00501980}

Submitted on 13 Jul 2010

HAL is a multi-disciplinary open access archive for the deposit and dissemination of scientific research documents, whether they are published or not. The documents may come from teaching and research institutions in France or abroad, or from public or private research centers.
L'archive ouverte pluridisciplinaire HAL, est destinée au dépôt et à la diffusion de documents scientifiques de niveau recherche, publiés ou non, émanant des établissements d'enseignement et de recherche français ou étrangers, des laboratoires publics ou privés. 


\section{Accepted Manuscript}

Nematode community dynamics over an annual production cycle in the central

North Sea

M. Schratzberger, R.M. Forster, F. Goodsir, S. Jennings

PII:

S0141-1136(08)00196-7

DOI:

10.1016/j.marenvres.2008.08.004

Reference:

MERE 3278

To appear in:

Marine Environmental Research

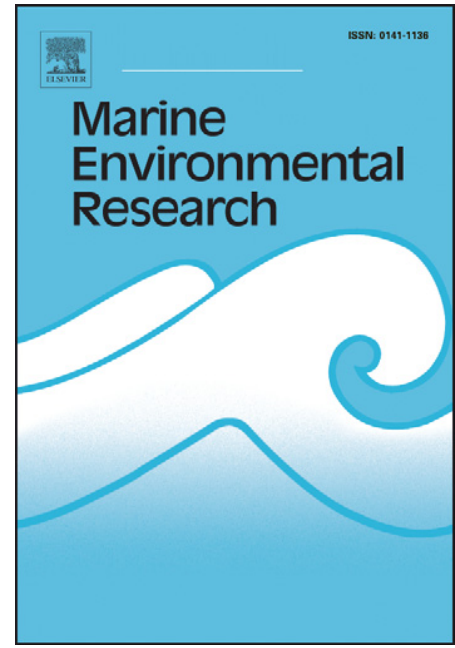

Received Date: $\quad 10$ June 2008

Revised Date: $\quad 5$ August 2008

Accepted Date: $\quad 6$ August 2008

Please cite this article as: Schratzberger, M., Forster, R.M., Goodsir, F., Jennings, S., Nematode community dynamics over an annual production cycle in the central North Sea, Marine Environmental Research (2008), doi: 10.1016/j.marenvres.2008.08.004

This is a PDF file of an unedited manuscript that has been accepted for publication. As a service to our customers we are providing this early version of the manuscript. The manuscript will undergo copyediting, typesetting, and review of the resulting proof before it is published in its final form. Please note that during the production process errors may be discovered which could affect the content, and all legal disclaimers that apply to the journal pertain. 
1

2

3

4

5

6

7

8

$9 *$ Corresponding author: Tel. $+44(0) 1502-527743$, Fax. $+44(0) 1502-513865$

10

Nematode community dynamics over an annual production cycle

in the central North Sea

\author{
M. Schratzberger*, R. M. Forster, F. Goodsir, S. Jennings
}

The Centre for Environment, Fisheries and Aquaculture Science, Lowestoft Laboratory, Pakefield Road, Lowestoft, Suffolk NR33 OHT, UK

\section{8}

(2) Corresponding anthor: Tel. $+44(0) 1502-527743$, Fax. $+44(0) 1502-513865$

E-mail address: michaela.schratzberger@cefas.co.uk (M. Schratzberger) 


\section{Abstract}

Nematode species composition, trophic structure and body size distributions were followed over an annual production cycle in the central North Sea; to test responses to temporally changing food quality and quantity in the sediment. Changes in the phytoplankton concentration in the water column were quantitatively reflected in the concentration of chlorophyll $a$ and breakdown products in the sediment, with higher concentrations in spring and autumn following blooms, and lower concentrations in summer and winter. The taxonomic and trophic structure of nematode communities differed significantly among stations over relatively short distances, potentially masking some of the temporal dynamics. Spatio-temporal differences in nematode species composition were linked to changes in the quality and quantity of organic material reaching the seabed, reflecting a species-specific response to the nutritional quality of sedimenting organic material and the biochemical changes in the sediment associated with its decomposition. The size distributions of selected nematode species indicated that most species bred continuously throughout the sampling period, although one species, the epigrowth feeder Spilophorella paradoxa, had periods of increased growth following the deposition of the spring phytoplankton bloom. There was no consistent temporal relationship between the trophic composition of nematode communities and spring chlorophyll $a$ or carbon sedimentation, most likely a result of the trophic plasticity of most feeding types and the capacity of the community to use both freshly sedimented material as well as the subsequent breakdown products and refractory organic matter. Community metrics implied that there were small responses to the seasonal production cycle, but these belied strong responses of a few species with life histories that allowed them to track the availability of suitable food resources.

Key words: Nematodes; Taxonomic and functional community composition; Benthic-pelagic coupling; Food quality; Food quantity; North Sea 


\section{Introduction}

The ecology of marine food webs at higher latitudes is strongly influenced by broadly predictable production cycles, driven by changes in nutrient supply, solar radiation and wind stress (Colebrook and Robinson, 1961). The production cycle in stratified temperate seas is characterised by one or more distinct phytoplankton blooms. The spring bloom is often dominated by larger-celled groups such as diatoms, followed by proliferation of nano- and picoplankton populations throughout the summer and autumn. The fate of carbon generated by phytoplankton depends on whether energy and nutrients fixed during blooms are recycled in the water column, exported to higher trophic levels or transferred to the seabed (Jago et al., 2007). After the bloom, fresh organic material sinking to the bottom is partly incorporated into the sediment as detrital particles or becomes adsorbed to sediment grains.

Sedimentation of organic matter represents the major input of production to the benthic community on an annual basis and is a major factor influencing benthic community structure, biomass and metabolism (Graf et al., 1982). Energy produced during annual production cycles propagates through the food web, with increasing lag and attenuation as it passes to larger animals with slower turnover times (Pope et al., 1994). Smaller benthic animals are likely to track the production cycle most closely, as their high relative rates of consumption and fast turnover times allow them to rapidly assimilate available production. The ecology and life histories of meiofauna (invertebrates that pass through a $500-1000 \mu \mathrm{m}$ mesh sieve but are retained on a $32-63 \mu \mathrm{m}$ mesh sieve; Giere, 1993) suggest that their population and community dynamics will respond to the seasonality of production.

Meiofauna play an important role as intermediaries between the microbial/detrital compartments (by influencing bacterial density and biomass; Mikola, 1998), and larger organisms (by serving as major food sources for higher trophic levels; Danovaro et al., 2007) in food webs (Chardy and Dauvin, 1992; Schmid-Araya et al., 2002). However, little is known about how food quality and quantity affect natural populations (Findlay, 1982; Danovaro and Gambi, 2002). Seasonal data on meiofauna abundance, reproduction and 
species composition are essential for conceptualising and modelling trophic dynamics (Fleeger, 1985) but to date, relationships between faunal characteristics and phytoplankton sedimentation have proven elusive. This is partly a result of the rarity of surveys which monitor phytoplankton sedimentation and faunal responses adequately. Thus most ecological studies of meiofauna have focused on intertidal or shallow subtidal habitats. When deeper water environments were studied, sampling designs rarely permitted repeated sampling at multiple stations or over more than one season (e.g. Vanaverbeke et al., 2004a and references therein).

Phytoplankton sedimentation is likely to affect meiofauna communities as many species live close to the sediment surface, feeding on diatoms and epigrowth (i.e. algal cells attached to particles). Fresh organic material is expected to reach deeper dwelling, deposit and bacteria feeding species during later stages of phytoplankton decomposition (Graf et al., 1982; Rudnick, 1989). Indeed, temperature and food availability are the factors most often invoked to explain seasonal changes in meiofaunal abundance (Heip et al., 1985; Ólafsson and Elmgren, 1997).

Taxon-based approaches are commonly used to study temporal dynamics of meiofauna. Aggregating taxonomically similar species or different developmental stages of the same species, however, does not take account of the diverse biology and autecological requirements of the organisms (Schratzberger et al., 2007). These issues have been taken into account by adopting functional and size-based approaches. The functional group approach classifies organisms by morphological characteristics that are thought or known to represent an important ecological function (Chalcraft and Resetarits, 2003). However, links between morphology and function can be weak and inconsistent, in some cases leading to an uncertain separation of taxonomic and functional approaches. The size-based approach focuses on the aggregation of organisms based on individual body weight, often independent of their taxonomy. Size is linked to processes such as metabolism and productivity, but size-based approaches may not reflect complex differences in the feeding ecology of different sized organisms. 
95 Since taxonomic, functional and size-based approaches focus on different aspects of 96 assemblage structure, a combination of all three methods is likely to provide better 97 understanding of seasonal changes in assemblage structure, dynamics and responses to changing food supply. Here, we study meiofaunal nematode community dynamics in the central North Sea to assess how taxonomic, trophic and biomass distribution patterns varied

100 during a seasonal production cycle. We relate community changes to changing food quality 101 and quantity in the sediment to investigate two questions:

102 (1) Does a local increase in food promote consistent temporal changes in the taxonomic, 103 trophic and size structure of nematode communities?

104 (2) Do selected nematode species, representing the main taxonomic and trophic categories 105 available to the phylum, respond in a differential way to a pulsed food supply?

\section{Material and methods}

108

111 We studied nematode communities in the Silver Pit, central North Sea (Fig. 1). The Silver Pit 112 is predominantly $60-80 \mathrm{~m}$ deep with a muddy-sand substratum and the water column 113 stratifies in summer months. Parts of the Silver Pit are fished by beam trawlers but there is 114 limited evidence that trawling disturbance has significant effects on nematode community 115 structure. Thus a previous experimental study in the Southern North Sea, investigating acute 116 effects of trawling disturbance on nematodes, showed that seasonal changes in assemblage 117 structure were greater than those attributed to trawling (Schratzberger et al., 2002). Sub118 surface temperature at $35 \mathrm{~m}$ depth at the sampling stations was low during spring and summer $119\left(6-8{ }^{\circ} \mathrm{C}\right.$ February to June, $9-10{ }^{\circ} \mathrm{C}$ in July), peaked in late summer $\left(11-16{ }^{\circ} \mathrm{C}\right.$ August to 120 October) and declined again during autumn and winter months $\left(8-10{ }^{\circ} \mathrm{C}\right.$ November to 121 January) (Paul McCloghrie, unpublished data). 
125 Sediment samples were collected with a NIOZ corer on six cruises in 2005 and 2006 (21 - 26

126 May, 12 - 16 July, 29 September - 4 October, 5 - 10 November 2005; 13 - 17 February, 26

127 April - 5 May 2006) from seven randomly chosen locations within $50 \mathrm{~m}$ of each of three

128 stations (Fig. 1). The NIOZ corer takes a circular core of $0.1 \mathrm{~m}^{2}$ to a depth of $>30 \mathrm{~cm}$. The

129 surface of the sediment core is relatively undisturbed, and the corer retains a few $\mathrm{cm}$ of the

130 overlying water.

131 From each deployment, two sediment sub-samples were collected with a perspex corer $(2 \mathrm{~cm}$

132 diameter, $3.14 \mathrm{~cm}^{2}$ surface area) to a depth of $5 \mathrm{~cm}$. On each sampling date, sub-samples were

133 combined by station and frozen at $-20{ }^{\circ} \mathrm{C}$ prior to the analysis of particle size and organic

134 carbon content. From each of the first three deployments, two further sub-samples were

135 collected, one for the analysis of sediment chlorophyll $a$, the other for the analysis of

136 sediment porosity. These sub-samples were frozen separately at $-20^{\circ} \mathrm{C}$ pending analysis. As

137 sediments reflect a time-averaged input of phytodetritus to the benthic system, sediment

138 chlorophyll $a$ concentrations are likely to show a more reliable pattern of annual algal

139 biomass and sedimentation than near-bottom water samples. Boon et al. (1998) and Franco et

140 al. (2007) showed that the typical algal spring bloom is quantitatively reflected in the

141 chlorophyll $a$ concentration of the majority of North Sea sediments.

142 From each of the last four deployments at each location, a meiofauna sub-sample was

143 collected with a $5.5 \mathrm{~cm}$ internal diameter perspex tube (surface area $23.76 \mathrm{~cm}^{2}$ ) to a depth of 5

$144 \mathrm{~cm}$. All faunal samples were fixed and preserved in $10 \%$ formalin in filtered seawater.

145

146 2.3. Sample processing

147 
148 After thawing, sediment samples were wet sieved through a $500 \mu \mathrm{m}$ sieve, and the fraction >

$149500 \mu \mathrm{m}$ was oven dried at $90{ }^{\circ} \mathrm{C}$ for $24 \mathrm{~h}$. This fraction was then dry sieved at 0.5 phi

150 intervals, down to 1 phi $(500 \mu \mathrm{m})$. The fraction $<500 \mu \mathrm{m}$ was freeze dried and analysed on a

151 Coulter LS 130 Laser sizer. The laser sizer results were combined with the dry sieve results to

152 give the full particle size distribution. The mean particle size diameter (hereafter referred to as

153 grain size) was calculated from these results (Dyer, 1986). The total organic carbon content of

154 the sediment fraction $<63 \mu \mathrm{m}$ was determined with a Leeman CE 440 elemental analyser.

155 Total organic carbon in the sediment consists of a variety of compounds with different

156 decomposition rates based on their structures and susceptibility to biological attack (Henrichs

157 and Doyle, 1986). Organic matter in the majority of marine sediments is complex and

158 generally of less degradable (i.e. refractory) nature (Fabiano and Danovaro, 1994).

159 Defrosted sediment chlorophyll $a$ samples were extracted in neutralised $90 \%$ acetone for $24 \mathrm{~h}$

160 at $4{ }^{\circ} \mathrm{C}$ in the dark. Measurements of extracted chlorophyll fluorescence were made (before

161 and after acidification with $8 \%$ hydrochloric acid to distinguish phaeopigments) using a

162 Turner Design (Model 10 AU) filter fluorometer (Tett, 1987). Sediment chlorophyll $a$ and

163 phaeopigment concentrations in the interstitial water were corrected for porosity, determined

164 from the dry weights and wet weights of known volumes of sediment. Sediment chlorophyll $a$

165 concentrations were used as an index of phytodetrital concentration (Boon and Duineveld,

166 1998). Temporal changes in chlorophyll $a$ breakdown products (phaeopigments) and

167 chlorophyll a:phaeopigment ratios were tracked as indices of phytoplankton bloom

168 degradation.

169 After washing the meiofauna samples onto a $38 \mu \mathrm{m}$ sieve, fauna were extracted with Ludox

170 TM 40 (Somerfield and Warwick, 1996). The extraction was repeated three times. The

171 extracts were sub-sampled following the method described by Somerfield and Warwick

172 (1996). Sub-samples of $5 \%$ of the extracted material (containing 85 - 448 nematodes,

173 average $=226$ nematodes) were evaporated slowly in anhydrous glycerol and mounted on

174 slides for further analysis. The numbers of individuals identified should give reasonable, and

175 comparable, estimates. Nematodes consistently comprised $>95 \%$ of total meiofauna 
abundance in all samples. Temporal dynamics of nematode communities in the Silver Pit

177 were investigated by analysing changes in their taxonomic and trophic composition as well as

178 changes in their size distribution.

179

180

\subsubsection{Taxonomic analysis}

181 All nematodes in each sub-sample were identified to genus or species level, using the 182 taxonomic keys of Platt and Warwick $(1983,1988)$ and Warwick et al. (1998) and the online 183 information system NeMys (Deprez, 2005; www.nemys.ugent.be). These are based on a 184 phylogenetic classification scheme, where the structure of the taxonomic tree approximates 185 the evolutionary relationships among organisms. Changes in phylogenetic diversity of species 186 assemblages, however, are not explicitly linked to changes in functional diversity and so their 187 ecological significance can be difficult to assess (Walker et al., 1999; Warwick and Clarke, 188 2001)

\subsubsection{Trophic analysis}

191 Despite the uniform organisation of free-living nematodes, a great diversity in mouth 192 structure exists which reflects the ecological role of the species (Heip et al., 1985). Based on 193 these morphological characteristics, Wieser (1953) devised a classification of feeding types 194 including selective deposit feeders consuming bacteria and small-sized organic particles, nonselective deposit feeders also feeding on organic deposits but targeting larger-sized particles,

196 epigrowth feeders scraping food off surfaces or feeding on diatoms and microalgae and

197 predators feeding on nematodes and other small invertebrates. The disadvantage of this

198 scheme is that it confines species to a single trophic role when many non-selective deposit 199 feeders are known to be omnivores. For example, while the omnivores may feed on particles 200 of a restricted size, their food can include bacteria, small flagellates and non-living 201 aggregates. Moreover, many selective deposit and epigrowth feeders feed on diatoms but 202 these are only numerous in shallow sediments and little is known about their diet in deeper 203 sediments (Heip et al., 1985) and some genera classed as predators may scavenge dead 
204 organic material as juveniles. Thus various authors have revised and modified Wieser's 205 classification (Romeyn and Bouwman, 1983; Jensen, 1987; Moens and Vincx, 1997; Moens 206 et al., 2004). However, in the absence of experimental evidence to describe the feeding habits 207 of most species, Wieser's scheme remains the most feasible trophic classification of free208 living marine nematodes from a variety of habitats.

\subsubsection{Size-based analysis}

211 Many biological and ecological processes are related to body size (Peters, 1983; Brown et al., 212 2004). In contrast to taxonomic and functional approaches, size-based analyses assume that 213 all organisms of the same size, independent of their taxonomic or functional identity, will 214 behave in approximately the same way in bioenergetic terms.

215 Individual body sizes were determined for nematodes in three of the four faunal replicates.

216 One percent of all nematodes in each replicate (corresponding to a total of 2454 individuals), 217 irrespective of species identity, were randomly selected for the calculation of individual body 218 mass from allometric relationships linking body dimensions to mass. Nematode length 219 (except long, filiform tails where present) and maximum width were measured using image 220 analysis (Image Pro Plus version 4.5). The body mass of individuals was then calculated with 221 the formulae of Andrassy (1956). Although more laborious, this volumetric, as opposed to a 222 gravimetric, method was chosen since it is non-destructive and keeps measured specimens 223 intact for taxonomic identification and the analysis of size distributions (Udalov et al., 2005).

224 Nematode size distributions were described for each sample by assigning individuals to $\log _{2}$

225 body-mass classes and calculating the proportion of all individuals in each class.

226 The similarities percentages procedure (SIMPER; Clarke, 1993) was used to identify species 227 that consistently contributed to spatio-temporal differences between assemblages. These 228 included the epigrowth feeder Spilophorella paradoxa, the non-selective deposit feeder 229 Sabatieria punctata and the selective deposit feeder Leptolaimus elegans and individual body 230 mass was therefore also estimated for these species separately. The percentages of organisms 231 measured were $3 \%$ of all Sabatieria punctata (corresponding to a total of 1479 individuals) 
232

233

234

235

236

237

238

239

240

241

242

243

244

and $5 \%$ of all Spilophorella paradoxa and Leptolaimus elegans (corresponding to a total of 372 and 1129 individuals respectively).

\subsection{Coupling of sediment and water column chlorophyll a}

An archive of surface chlorophyll $a$ concentration images, derived from MODIS-Aqua satellite ocean colour data using a modified version of the case-II water algorithm 'OC5' (Gohin et al., 2002), was processed and supplied by Ifremer, France. This regional algorithm differs from generic, global satellite chlorophyll products in that additional sensor bands are used to correct for the presence of suspended sediments and the chromophoric (coloured) fraction of dissolved organic matter (cDOM). The surface chlorophyll maps cover the northwest Atlantic shelf at a resolution of $1 \mathrm{~km}^{2}$ and were made available for the time period June 2002 to present by the EU/ESA project MarCoast (Marine and Coastal Environmental Information Services; www.gmes-marcoast.com). Maps in the archive were queried with the 'Zonal Statistics' function of ArcMap version 9.2 in order to extract discrete chlorophyll $a$ values for the surface waters of the sampling stations A, B and C (Fig. 1). This approach provided a time-series of surface chlorophyll $a$ estimates for each station. Valid, cloud-free estimates of chlorophyll $a$ were obtained on approximately $23 \%$ of all days during the time period of the study. The pelagic chlorophyll $a$ values were then assembled, converted to monthly means and compared with chlorophyll $a$ concentrations in the sediment.

\subsection{Data processing}

\subsubsection{Univariate methods}

Spatial and temporal patterns of environmental variables were investigated using KruskalWallis one-way analysis by ranks where measures are transformed to ranks, ignoring group membership. The ranks were used to test the null-hypothesis $\left(\mathrm{H}_{0}\right)$ that there was no significant 
259 shift in the centre of the groups between stations and over time. There was no statistically

260 significant co-variation between the environmental measures included in the analyses.

261 Total nematode abundance, species diversity of the entire community and diversity within the

262 four feeding types (H') were calculated from the species abundance data (Shannon and

263 Weaver, 1949):

264

265

$H^{\prime}=\sum_{i=1}^{S} p_{i}\left(\ln p_{i}\right)$

266

267 where $p_{\mathrm{i}}$ is the number of individuals in the $\mathrm{i}^{\text {th }}$ species $\left(n_{i}\right)$ divided by the total number of 268 individuals $(N)$.

269

270 The Index of Trophic Diversity (ITD), based on the proportion of each of four feeding types

271 was calculated following Heip et al. (1985). ITD values range from 0.25 (highest trophic 272 diversity with the four trophic groups accounting for $25 \%$ each) to 1.0 (lowest trophic 273 diversity when a single feeding type is present):

274

$275 \quad \mathrm{ITD}=\sum \theta^{2}$

276

277 where $\theta$ is the percentage contribution of each of four feeding types according to Wieser 278 (1953).

279

280 Average individual body mass was calculated from the body dimensions across all species 281 present in the total nematode community and for populations of Spilophorella paradoxa, 282 Sabatieria punctata and Leptolaimus elegans.

283 Bartlett's and Cochran's tests were used to test for homogeneity of variance before spatio284 temporal variations in all community attributes were analysed by two-way analysis of 285 variance (ANOVA). Following the detection of significant 'station' and sampling 'month' 
286 effects, the Tukey HSD multiple comparisons test was used in pair-wise comparisons of 287 samples. When the interaction term station $\mathrm{x}$ month was significant, the two-way ANOVA 288 was broken down to a one-way ANOVA.

289 All univariate statistical analyses were performed using the software package Statgraphics 290 Plus version 3.3.

291

\subsubsection{Multivariate methods}

293 Non-metric multi-dimensional scaling (MDS) ordination using the Bray-Curtis similarity 294 measure (Clarke et al., 2006) was applied to the relative abundance (i.e. proportion) of 295 species, feeding types and geometric size classes (Clarke and Warwick, 2001). The statistical 296 significance of spatial differences (averaged over the 12-month study period) and changes in 297 distribution patterns over time (averaged over the three stations) were assessed by two-way 298 crossed analysis of similarities (ANOSIM; Clarke, 1993), a non-parametric analogue of the 299 univariate ANOVA.

300 BIO-ENV (Clarke and Ainsworth, 1993) and BVSTEP (Clarke and Warwick, 1998) were 301 used to investigate relationships between environmental variables and the species, feeding 302 type and size composition of nematode communities. Spearman rank correlations (R) between 303 resemblance matrices derived from faunal data (based on Bray-Curtis similarity) and matrices 304 derived from various sub-sets of environmental data (based on normalised Euclidean 305 Distance) were used to identify suites of variables that best explained observed community 306 patterns. The significance of the correlations was determined using a permutation procedure 307 (Stoffels et al., 2005).

308 All multivariate statistical analyses were performed using Primer version 6.1.5 (Clarke and 309 Gorley, 2006).

\section{3. Results}


315 All stations comprised soft bottom, muddy habitat. Stations were comparable with respect to 316 water depth (A: $63 \mathrm{~m}, \mathrm{~B}: 64 \mathrm{~m}, \mathrm{C}: 55 \mathrm{~m}$ ) and sediment granulometry, although grain size at station $\mathrm{C}$ was slightly smaller than at station A and B (Table 1). The silt-clay content of the

318 sediment did not differ significantly between stations and seasons, nor did the content of total 319 organic carbon (Table 2). A temporal trend in chlorophyll $a$ and phaeopigment concentrations 320 in the sediment was apparent with a distinct peak in May 2005 and to a lesser extent in 321 September 2005 (Tables 1 and 2, Fig. 2).

\subsection{Coupling of sediment and water chlorophyll a}

324

Pelagic chlorophyll $a$ concentrations were typically higher to the north and to the south of the Silver Pit than over the central Silver Pit (see Fig. 1 for a monthly composite image of April 2005). Time series analysis showed that the spring bloom started in the first week of April in both 2005 and 2006. Water chlorophyll $a$ concentration was low in summer in both years, especially at station C (Fig. 3). It is likely that a deep chlorophyll maximum is present during this period of strongly stratified conditions (Olesen, 1995; Richardson et al., 2000), but this cannot be detected by the satellite. There was an autumn bloom in both years peaking during late September and early October. The spring bloom of 2006 was more pronounced than in 2005.

The most productive station was station A with a mean water chlorophyll $a$ concentration of $0.75( \pm 0.60) \mathrm{mg} \mathrm{m}^{-3}$ over the study period. Station B was intermediate with $0.64( \pm 0.44) \mathrm{mg}$ $\mathrm{m}^{-3}$ and station $\mathrm{C}$ was lowest with a mean value of $0.55( \pm 0.37) \mathrm{mg} \mathrm{m}^{-3}$. Hence there was a gradient in pelagic productivity through the Silver Pit from west (high) to east (low), with station A being closest to the areas of high primary production to the north and south of the Silver Pit (Fig. 1). Higher phytoplankton abundance at the surface was reflected in higher pigment concentrations in the upper layers of the sediment, particularly during the spring 
341 bloom of both years (Fig. 3). However, the relationship between surface production and

342 benthic deposition differed considerably between 2005 and 2006 (Fig. 3). It is unknown to

343 what extent the settling particles are buried in the sediment at the place they arrive on the

344 seafloor and how much is lost to other areas by advection near the sediment surface.

345 The temporal variability of pulses of primary production reaching the seafloor along the

346 gradient of pelagic productivity allowed us to investigate the relationship between nematode

347 taxonomic, trophic and size structure and changes in food quality and quantity.

\subsection{Nematode species and feeding types}

351 The analysis of spatio-temporal differences in community-related measures (Table 3) showed 352 that density, species diversity and trophic diversity were higher at station A and B than at 353 station C. Similar trends were recorded for species diversity within the four feeding types 354 (data not shown). Spatial differences in univariate community attributes were generally more 355 pronounced than temporal trends. With the exception of trophic diversity (ITD), the 356 magnitude and direction of spatial differences were maintained throughout the 12-month 357 study period. ITD did not change significantly over time at station A and B and decreased 358 within the first 9 months at station $\mathrm{C}(p=0.059)$. Communities at station $\mathrm{C}$ were most 359 trophically diverse in February 2006.

360 Across all three stations, proportions of the epigrowth feeder Spilophorella paradoxa were 361 consistently lower in winter (November 2005) than in spring (May 2005 and April 2006,

362 Table 3, Fig. 4). The non-selective deposit feeder Sabatieria punctata dominated nematode 363 communities at station B. Spatial distributions of Leptolaimus elegans were not consistent 364 over time nor were temporal dynamics of this species consistent among stations. While 365 relative abundance remained temporally stable at station $\mathrm{B}$ and $\mathrm{C}$, values at station A were 366 significantly increased in November 2005 following the autumn bloom (Table 3).

367 As shown in Table 4, the relative abundance of selective deposit feeders $(\mathrm{F}=78.56, p<$ $3680.001)$ and predators $(\mathrm{F}=15.43, p<0.001)$ were lowest at station $\mathrm{C}$ whereas communities at 
station A were characterised by relatively low proportions of epigrowth feeders $(\mathrm{F}=26.75, p$

$370<0.001)$. Lowest proportions of non-selective deposit feeders were recorded at station $\mathrm{B}(\mathrm{F}=$

$3716.12, p=0.004)$. Temporal patterns of nematode feeding types were inconsistent amongst

372 stations and generally not statistically significant at $p>0.05$.

373 There were significant spatial differences in distribution patterns of nematode species $(\mathrm{R}=$

$3740.583, p=0.001)$ and feeding guilds $(\mathrm{R}=0.492, p=0.001)$ and these generally dominated

375 temporal dissimilarities (species assemblages: $\mathrm{R}=0.213, p=0.001$, trophic groups $\mathrm{R}=0.065$, $376 p=0.089$; Fig. 5).

377 Distribution patterns of nematode species were correlated with grain size, total organic carbon 378 content in the sediment and sedimentary chlorophyll $a$ :phaeopigment ratios $(\mathrm{R}=0.533, p=$ 379 0.010). Spatial differences in species distribution patterns were most marked in May 2005 380 when station-specific differences in chlorophyll a:phaeopigment ratios were highest (Table 1). 381 A combination of grain size and total organic carbon content in the sediment best explained 382 the trophic structure of assemblages $(\mathrm{R}=0.424, p=0.010)$. Spatial differences in the trophic 383 structure of nematode assemblages were most pronounced in April 2006 and coincided with 384 low levels of total organic carbon in the sediment (Table 1).

\subsection{Nematode body size}

Spatially significant differences in individual body mass across the entire community

389 included a higher average individual body mass at station $\mathrm{C}$ than at station A and B whereas

390 the opposite trend was observed for populations of the epigrowth feeder Spilophorella 391 paradoxa and the non-selective deposit feeder Sabatieria punctata (Table 5). Average 392 individual body mass remained stable over the 12-month study period for the total community 393 and for Sabatieria punctata and Leptolaimus elegans populations. Individual body mass of 394 Spilophorella paradoxa, in contrast, peaked in September 2005 at all stations (Fig. 6).

395 In contrast to functional analyses, the investigation of the distribution of both absolute (not 396 shown) and relative nematode abundance across body size classes revealed significant 
temporal differences. Conversely, spatial differences were less pronounced when the total

398 community was taken into account (Table 6). We observed a shift from larger to smaller

399 individuals over the 12-month production cycle but this could not be linked to any of the

400 measured environmental variables $(p>0.05)$.

401 At all three sampling stations, populations of the epigrowth feeder Spilophorella paradoxa

402 were dominated by mature adults, as indicated by an abundance peak in size class -1 (Fig. 7).

403 Significant spatial and temporal dissimilarities in the body size distribution (Table 6) were

404 clearly related to differences in the total organic carbon content and the progression of 405 chlorophyll $a$ decomposition (i.e. chlorophyll a:phaeopigment ratio) in the sediment 406 throughout the annual production cycle $(\mathrm{R}=0.368, p=0.040)$. There was a clear temporal 407 succession in the size distribution of individuals in the population of Spilophorella paradoxa 408 (Fig. 8) following deposition of the spring phytoplankton bloom in May 2005 and its 409 decomposition over the following 11 months. Relatively high levels of both fresh (i.e. high 410 chlorophyll a:phaeopigment ratios) and refractory (i.e. total organic carbon content) organic 411 material in the sediment in May 2005 coincided with approximately equal proportions of 412 juveniles and adults in the population, indicating continuous asynchronous breeding. Adults 413 clearly dominated in July and September 2005 when sub-surface temperatures peaked and 414 food availability was still high. The abundance of small individuals increased and that of 415 larger individuals decreased over the winter months (November 2005 to February 2006) as 416 both sub-surface temperatures and carbon resources in the sediment declined. The distribution 417 of individuals among size classes was most homogeneous in April 2006, prior to the 418 deposition of material from the next spring bloom.

\section{Discussion}

422 It has been estimated that sedimentation of organic matter accounts for approximately half of 423 net primary production in stratified parts of UK shelf seas (Jago et al., 2007). Here we show 424 from paired observations of pelagic and benthic pigment concentration that the degree of 
425 transfer between surface and sediment is not constant, and can differ greatly between

426 locations and years. The approximately two-fold higher concentration of phytoplankton in the

427 water column over the Silver Pit during April 2006 did not result in enhanced benthic

428 chlorophyll or carbon concentrations. This could be due to the combined effects of

429 differences in (1) the rate of pelagic consumption (e.g. grazing), (2) local hydrodynamics,

430 resulting in sedimentation of the phytoplankton at other locations and (3) the timing of

431 benthic sample collection (i.e. time elapsed following the pelagic phytoplankton bloom). In

432 the absence of light measurements and live observation of microalgal cells, in situ benthic

433 primary production in the Silver Pit cannot be ruled out (McGee et al., 2008). However,

434 investigating sediments from the Dogger Bank in the central North Sea, Reiss et al. (2007)

435 showed that stations below $40 \mathrm{~m}$ water depth were characterised by a phytopigment

436 composition originating from pelagic phytoplankton settled on the sea floor.

437 Nematode assemblages were studied at three stations in the Silver Pit area of the central North

438 Sea during a 12-month production cycle to identify the relative importance of different

439 environmental factors (including the quality and quantity of organic material reaching the

440 seafloor) in controlling their taxonomic, trophic and biomass distribution patterns. Our data

441 suggest that spatio-temporal differences in nematode species composition were partly a

442 response to the sedimentation of pelagic production and appeared to reflect species-specific

443 responses to its nutritional quality. These correlative relationships provide valuable pointers

444 to the mechanisms potentially causing the observed variation.

446 4.1. Does a local increase in food promote consistent temporal changes in the taxonomic,

447 trophic and size structure of nematode communities?

449 The taxonomic and trophic structure of nematode communities differed significantly among

450 stations over relatively short distances, potentially masking some of the temporal dynamics.

451 Nematode assemblages appeared to respond to spatial gradients of declining grain size and

452 pelagic productivity in the Silver Pit from west to east as evidenced by decreasing density, 
453 species diversity and trophic diversity. Taking the entire community into account, average

454 individual body size increased with decreasing grain size and pelagic productivity. This result

455 was counter to the analysis of Udalov et al. (2005) who investigated the relationship between

456 mean nematode individual weight, sediment granulometry and food availability from 120

457 worldwide locations in the depth range $0-8260 \mathrm{~m}$. In their analysis, nematode size increased

458 with particle diameter and the concentration of sediment-bound chloroplastic pigments.

459 However, the overall relationships masked more complex patterns within habitat types.

460 Variability of generally more diverse, coarser sediments at shallower depths compared to

461 fluid clays and oozes in the deep sea were mainly responsible for the changes in the nematode

462 size structure from shelf to slope. Thus, the relationships between sediment granulometry and

463 nematode size were strong for intertidal and shallow subtidal habitats but weaker for deeper

464 subtidal areas. Equally, although Udalov et al. (2005) found evidence for decreases in the size

465 of nematodes with decreasing food availability, the correlation with nematode size was

466 significant for oligotrophic areas only and weakened when organic input was sufficient to

467 cover the higher energy consumption rates of larger species (Warwick and Price, 1979). Low

468 pelagic productivity and small grain size at the easternmost station in the Silver Pit resulted in

469 high proportions of large-bodied non-selective deposit and epigrowth feeders in the nematode

470 community whereas the density and diversity of their smaller-sized bacteria feeding

471 congeners was reduced.

472 Although spatial differences in species composition dominated temporal dynamics,

473 significant temporal changes were recorded over the 12-month production cycle. These were

474 linked to changes in the quality and quantity of organic material reaching the seabed, as

475 indicated by the chlorophyll $a$ :phaeopigment ratio and the total organic carbon content.

476 Davies and Payne (1984) provided evidence of a large settlement of diatoms immediately

477 after the spring bloom in the northern North Sea, based on changes in the biochemical

478 composition of material collected in moored sediment traps. The significant relationship

479 between species distribution patterns and the state of phytoplankton remineralisation might

480 thus point towards a species-specific response to the nutritional quality of sedimenting 
481 organic material and the biochemical changes in the sediment associated with its

482 decomposition (e.g. oxygenation, alterations in decomposer communities such as bacteria 483 etc.).

484 There was no consistent temporal relationship between the trophic composition of nematode 485 communities and spring chlorophyll $a$ or carbon sedimentation, most likely a result of the 486 trophic plasticity of most feeding types. Thus different species belonging to one trophic guild 487 may be able to forage on different food sources and/or exploit their food at different rates (De 488 Mesel et al., 2004; Postma-Blaauw et al., 2005). Investigating the uptake of a radio-labelled 489 diatom by meiofauna species in a laboratory experiment, Ólafsson et al. (1999) found that 490 nematodes with similar buccal cavities and of similar size showed surprisingly large 491 differences in uptake, suggesting a strong selection both for and against the diatom among 492 epigrowth and non-selective deposit feeders. Likewise, also in a laboratory study, Moens et 493 al. (1999) demonstrated a highly species-specific response of bacteria feeding nematodes to 494 different types, densities and age structures of bacterial strains.

495

498

500

501

4.2. Do selected nematode species, representing the main taxonomic and trophic categories available to the phylum, respond in a differential way to a pulsed food supply?

Phytoplankton sedimentation in stratified temperate marine waters is distinctly seasonal, but the majority of studies in subtidal environments found no unequivocal influence of sedimentation on the density and biomass of meiofaunal nematodes (Heip et al., 1985; Ólafsson et al., 1999). However, the apparent absence of a community response may be misleading. Phytoplankton during and after bloom conditions may settle quickly to the seafloor and these fresh cells may be largely intact and rich in nutrients (Graf, 1992; Richardson et al., 2000). Sedimented phytoplankton might be directly ingested or contribute to the microbial loop, ultimately increasing meiofaunal food supply. Fleeger et al. (1989) hypothesised that this variation in phytoplankton settlement might affect meiofaunal survivorship and reproductive success. Our results suggest that populations of species, 
509

510

511

512

513

514

515

516

517

518

519

520

521

522

523

524

525

526

527

528

529

530

531

532

533

534

535

536

assumed to feed on fresh organic material such as Spilophorella paradoxa, can exhibit temporal patterns in their abundance and size distribution. Given the seasonal cycle of detrital sedimentation, the balance of benthic food input and demand may shift seasonally, with spring surpluses followed by deficits later in the year. Across all three stations, relative abundance of Spilophorella paradoxa declined following the spring phytoplankton bloom in May 2005 and reached the lowest values the following November. This suggests that food deficits may be particularly acute for those species that feed at the sediment-water interface and depend on fresh inputs, although other unmeasured factors, such as competition for food, are also likely to influence population dynamics.

Temporal dynamics of Spilophorella paradoxa populations were clearly linked to the quality and quantity of organic material present in the sediment throughout an annual production cycle, confounded by annual fluctuations in sub-surface temperature. Temperature may trigger or terminate reproductive activities of nematodes and determine the development time of juveniles. Generally, higher ambient temperatures result in shorter development times; however, little is known of the development time of most species (Warwick and Price, 1979 and references therein; Moens and Vincx, 2000a). High concentrations of fresh and refractory organic material in the sediment and rising sub-surface temperatures in the Silver Pit in May 2005 resulted in approximately equal proportions of juveniles and adults in the population. Developmental time decreased as ambient temperatures increased, leading to adult-dominated populations in July and September 2005 when food availability was still sufficient to cover their metabolic demands. Declining food availability and temperatures slowed growth and, potentially, reproduction in subsequent months, leading to low numbers of individuals across the entire size spectrum in November 2005. The abundance peak of adults in summer 2005 was followed by an increase of juveniles between February and April 2006 when temperatures in the sediment began to increase prior to the deposition of the spring phytoplankton bloom.

Many deeper dwelling, deposit-feeding nematodes, including populations of Sabatieria punctata and Leptolaimus elegans may not be able to use sedimenting phytoplankton as food 
537 directly and they may rely on the microbial loop to stimulate bacterial production from 538 sedimented material. Results from experimental studies, investigating the importance of 539 freshly produced phytoplankton detritus in the diet of meiofauna are conflicting. Rudnick 540 (1989) hypothesised that, in contrast to surface-dwelling nematodes, the food resources of 541 sub-surface deposit feeders are more stable because they have access to and assimilate a 542 portion of the buried pool of older organic matter. Consequently, one might not expect 543 consistent temporal changes in their density and size distribution. Ólafsson et al. (1999) 544 contradicted this hypothesis by revealing that sub-surface dwelling nematode species can 545 assimilate as much phytoplankton carbon per unit biomass as surface dwellers. Recently, 546 Franco et al. (2008) showed that Sabatieria-species can benefit from sedimenting 547 phytoplankton by moving to the sediment surface.

548 Patterns of food availability for deposit feeding organisms can be spatially and temporally 549 complex and total organic carbon measurements might be inadequate to elucidate the 550 mechanisms by which food abundance and variety regulate the organisation of deposit551 feeding assemblages (Whitlach, 1981). Whilst such measures provide information on the total 552 standing stock of organic carbon, they generally overestimate its labile, readily utilisable 553 fraction. At the same time, all living components (e.g. bacteria, microphytobenthos, 554 protozoans) represent a high-quality food source but generally account for a minor fraction of 555 the sediment organic carbon pools (Fabiano and Danovaro, 1994; Danovaro and Gambi, 556 2002).

557

558 5. Conclusions

560 Biomass-size distributions showed the most consistent temporal patterns in nematode 561 assemblages. When applied to the whole community, the size-based approach has significant 562 advantages over taxon-based and functional approaches through its simplicity, since it avoids 563 distinguishing between taxonomic groups or defining distinct trophic guilds (Soetaert et al., 564 2002). Our results from the central North Sea show that the relationship between 
565 phytoplankton sedimentation and meiofaunal response is complex and that community 566 responses are weaker than those of some of the component species. Hence, size-based 567 analyses provided the most insightful results when performed on selected species.

568 The differential responses within communities reflect different life histories and feeding 569 modes and the changes in the resources available during the seasonal production cycle. The 570 rate of response indicates that the life histories of meiofauna allow their populations to track 571 the availability of suitable food resources. Since the feeding habits of most meiofauna species 572 are not well known, the majority of previous studies on the structure and connectedness of 573 aquatic food webs have ignored meiofaunal taxa or aggregated them into broad functional 574 groups. Existing food web data are therefore strongly biased towards trophically higher 575 organisms. Our findings suggest that future investigations of the relationship between size576 structure of meiofauna populations (Vanaverbeke et al., 2004b) and potential food sources 577 (Dauwe and Middelburg, 1998), factors regulating meiofauna fecundity (e.g. food, 578 temperature; Moens and Vincx, 2000b) as well as novel information on species-specific 579 feeding habits and preferences (Moens and Vincx, 1999) are crucial to the understanding of 580 their role in food webs.

\section{Acknowledgements}

584 We thank the scientists, officers and crew of RV 'Cefas Endeavour' for practical assistance in 585 the collection of samples. Claire Mason conducted the particle size analyses and Olga Andres 586 carried out phytopigment analyses. We are grateful to Paul Whomersley and Tracy Maxwell

587 for processing the meiofauna samples. The work was supported by the Department for 588 Environment, Food and Rural Affairs (research projects MF10 and ME4118).

\section{References}


592

593

594

595

596

597

598

599

600

601

602

603

604

605

606

607

608

609

610

611

612

613

614

615

616

617

618

Andrassy, I., 1956. Die Rauminhalts- und Gewichtsbestimmung der Fadenwürmer (Nematoden). Acta Zoologica 2, 1-14.

Boon, A.R., Duineveld, G.C.A., 1998. Chlorophyll $a$ as a marker for bioturbation and carbon flux in southern and central North Sea sediments. Marine Ecology Progress Series 162, $33-43$.

Boon, A.R., Duineveld, G.C.A, Berghuis, E.M., van der Weele, J.A., 1998. Relationships between benthic activity and the annual phytopigment cycle in near-bottom water and sediments in the southern North Sea. Estuarine, Coastal and Shelf Science 46, 1-13.

Brown, J.H., Gillooly, J.F., Allen, A.P., Savage, V.M., West, G.B., 2004. Towards a metabolic theory of ecology. Ecology 85, 1771-1789.

Chalcraft, D.R., Resetarits, W.J., 2003. Mapping functional similarity of predators on the basis of trait similarities. American Naturalist 162, 390-402.

Chardy, P., Dauvin, J.-P., 1992. Carbon flows in a subtidal fine sand community from the western English Channel: a simulation analysis. Marine Ecology Progress Series 81, 147161.

Clarke, K.R., 1993. Non-parametric multivariate analyses of changes in community structure. Australian Journal of Ecology 18, 117-143.

Clarke, K.R., Ainsworth, M., 1993. A method of linking multivariate community structure to environmental variables. Marine Ecology Progress Series 92, 205-219.

Clarke, K.R., Warwick, R.M., 1998. Quantifying structural redundancy in ecological communities. Oecologia 113, 278-289.

Clarke, K.R., Warwick, R.M., 2001. Change in marine communities: an approach to statistical analysis and interpretation. $2^{\text {nd }}$ edition, Primer-E Ltd, Plymouth, UK, 172 pp.

Clarke, K.R., Gorley, R.N., 2006. PRIMER v6. User manual. Primer-E Ltd., Plymouth, UK, $190 \mathrm{pp}$.

Clarke, K.R., Somerfield, P.J., Chapman, M.G., 2006. On resemblance measures for ecological studies, including taxonomic dissimilarities and zero-adjusted Bray-Curtis 
619

620

621

622

626

628

630

632

634

635

636

637

641

642

643

644

645

646

coefficient for denuded assemblages. Journal of Experimental Marine Biology and Ecology 330, 55-80.

Colebrook, J.M., Robinson, G.A., 1961. The seasonal cycle of the plankton in the North Sea and the north-eastern Atlantic. Journal du Conseil Permanent International pour l'Exploration de Mer 26, 156-165.

Danovaro, R., Gambi, C., 2002. Biodiversity and trophic structure of nematode assemblages in seagrass systems: evidence for a coupling with changes in food availability. Marine Biology 141, 667-677.

Danovaro, R., Scopa, M., Gambi, C., Fraschetti, S., 2007. Trophic importance of subtidal metazoan meiofauna: evidence from in situ exclusion experiments on soft and rocky substrates. Marine Biology 152, 339-350.

Dauwe, B., Middelburg, J.J., 1998. Amino acids and hexosamines as indicators of organic matter degradation state in North Sea sediments. Limnology and Oceanography 43, 782789.

Davies, J.M., Payne, R., 1984. Supply of organic matter to the sediment in the northern North Sea during a spring phytoplankton bloom. Marine Biology 78, 315-324.

De Mesel, I., Derycke, S., Moens, T., Van der Gucht, K., Vincx, M., Swings, J., 2004. Topdown impact of bacterivorous nematodes on the bacterial community structure: a microcosm study. Environmental Microbiology 6, 733-744.

Deprez, T., 2005. NeMys. World Wide Web electronic publication, www.nemys.ugent.be, version $(2 / 2008)$.

Dyer, K.R., 1986. Coastal and estuarine sediment dynamics. John Wiley \& Sons, Chichester, UK, $342 \mathrm{pp}$.

Fabiano, M., Danovaro, R., 1994. Composition of organic matter in sediments facing a river estuary (Tyrrhenian Sea): relationships with bacteria and microphytobenthic biomass. Hydrobiologia 277, 71-84.

Findlay, S.E.G., 1982. Effect of detrital nutritional quality on population dynamics of a marine nematode (Diplolaimella chitwoodi). Marine Biology 68, 223-227. 
647 Fleeger, J.W., 1985. Meiofaunal densities and copepod species composition in a Louisiana, 648 USA, estuary. Transactions of the American Microscopical Society 104, 321-332.

649 Fleeger, J.W., Shirley, T.C., Ziemann, D.A., 1989. Meiofaunal responses to sedimentation 650 from an Alaskan spring bloom. I. Major taxa. Marine Ecology Progress Series 57, 137$651 \quad 145$

652 Franco, M.A., De Mesel, I., Demba Diallo M., Van der Gucht, K., Van Gansbeke, D., van 653 Rijswijk, P., Costa, M.J., Vincx, M., Vanaverbeke, J., 2007. Effect of phytoplankton 654 bloom deposition on benthic bacterial communities in two contrasting sediments in the 655 southern North Sea. Aquatic Microbial Ecology 48, 241-254.

656 Franco, M.A., Soetaert, K., Van Oevelen, D., Van Gansbeke, D., Costa, M.J., Vincx, M., 657 Vanaverbeke, J., 2008. Density, vertical distribution and trophic responses of metazoan 658 meiobenthos to phytoplankton deposition in contrasting sediment types. Marine Ecology 659 Progress Series 358, 51-62.

660 Giere, O., 1993. Meiobenthology - the microscopic fauna in aquatic sediments. Springer $661 \quad$ Verlag, Berlin, Germany, 328 pp.

662 Gohin, F., Druon, J.N., Lampert, L., 2002. A five channel chlorophyll concentration 663 algorithm applied to Sea WiFS data processed by SeaDAS in coastal waters. International 664 Journal of Remote Sensing 23, 1639-1661.

665 Graf, G., Bengtsson, J., Diesner, U., Schulz, R., Theede, H., 1982. Benthic response to 666 sedimentation of a spring phytoplankton bloom: process and budget. Marine Biology 67, $667 \quad 201-208$.

668 Graf, G., 1992. Benthic-pelagic coupling: a benthic view. Oceanography and Marine Biology: 669 an Annual Review 30, 149-190.

670 Henrichs, S.M., Doyle, A.P., 1986. Decomposition of ${ }^{14} \mathrm{C}$-labelled organic substances in 671 marine sediments. Limnology and Oceanography 31, 765-778.

672 Heip, C., Vincx, M., Vranken, G., 1985. The ecology of marine nematodes. Oceanography 673 and Marine Biology: an Annual Review 23, 399-489. 
674 Jago, C.F., Kennaway, G.M., Novarino, G., Jones, S.E., 2007. Size and settling velocity of 675 suspended flocs during a Phaeocystis bloom in the tidally stirred Irish Sea, NW European 676 shelf. Marine Ecology Progress Series 345, 51-62.

677 Jensen, P., 1987. Feeding ecology of free-living aquatic nematodes. Marine Ecology Progress $678 \quad$ Series $35,187-196$.

679 McGee, D., Laws, R.A., Cahoon, L. B., 2008. Live benthic diatoms from the upper 680 continental slope: extending the limits of marine primary production. Marine Ecology $681 \quad$ Progress Series, 356, 103-112.

682 Mikola, J., 1998. Effects of microbivore species composition and basal resource enrichment 683 on trophic-level biomasses in an experimental microbial-based soil food web. Oecologia $684 \quad 117,396-403$.

685 Moens, T., Vincx, M., 1997. Observations on the feeding ecology of estuarine nematodes. 686 Journal of the Marine Biological Association of the United Kingdom 77, 211-227.

687 Moens, T., Vincx, M., 1999. Do meiofauna consume primary production? About many 688 questions and how to answer them, in: Dehairs, B.J.F., Goeyens, L. (Eds.), Integrated 689 Marine Systems Analysis, European Network for Integrated Marine Systems Analysis, 690 Minutes of the First Network Meeting, Brugge, Belgium, pp. 188-202.

691 Moens, T., Verbeek, L., de Maeyer, A., Swings, J., Vincx, M., 1999. Selective attraction of 692 marine bacterivorous nematodes to their bacterial food. Marine Ecology Progress Series $693 \quad 176,165-178$.

694 Moens, T., Vincx, M., 2000a. Temperature and salinity constraints on the life cycle of two 695 brackish-water nematode species. Journal of Experimental Marine Biology and Ecology, $696243,115-135$.

697 Moens, T., Vincx, M., 2000b. Temperature, salinity and food thresholds in two brackishwater 698 bacterivorous nematode species: assessing niches from food absorption and respiration 699 experiments. Journal of Experimental Marine Biology and Ecology 243, 137-154.

700 Moens, T., Yeates, G.W., De Ley, P., 2004. Use of carbon and energy sources by nematodes. $701 \quad$ Nematology Monographs and Perspectives 2, 529-545. 
702 Ólafsson, E., Elmgren, R., 1997. Seasonal dynamics of sublittoral meiobenthos in relation to 703 phytoplankton sedimentation in the Baltic Sea. Estuarine, Coastal and Shelf Science 45, $704 \quad 149-164$.

705 Ólafsson, E., Modig, H., van de Bund, W.J., 1999. Species specific uptake of radio-labelled 706 phytodetritus by benthic meiofauna from the Baltic Sea. Marine Ecology Progress Series $707 \quad 177,63-72$.

708 Olesen, M., 1995. Comparison of the sedimentation of a diatom spring bloom and of a 709 subsurface chlorophyll maximum. Marine Biology 121, 541-547.

710 Peters, R.H., 1983. The ecological implications of body size. Cambridge University Press, 711 Cambridge, UK, 329 pp.

712 Platt, H.M., Warwick, R.M., 1983. Free-living marine nematodes. Part I. British enoploids. 713 Cambridge University Press, Cambridge, UK, 307 pp.

714 Platt, H.M., Warwick, R.M., 1988. Free-living marine nematodes. Part II. British 715 chromadorids. Cambridge University Press, Cambridge, UK, 502 pp.

716 Pope, J.G., Shepherd, J., Webb, J., 1994. Successful surf-riding on size spectra: the secret of 717 survival in the sea. Philosophical Transactions of the Royal Society 343, 41-49.

718 Postma-Blaauw, M.B., de Vries, F.T., de Goede, R.G.N., Bloem, J., Faber, J.H., Brussaard, 719 L., 2005. Within-trophic group interactions of bacterivorous nematode species and their 720 effects on the bacterial community and nitrogen mineralization. Oecologia 142, 428-439.

721 Reiss, H., Wieking, G., Kröncke, I., 2007. Microphytobenthos of the Dogger Bank: a 722 comparison between shallow and deep areas using phytopigment composition of the 723 sediment. Marine Biology 150, 1061-1071.

724 Richardson, K., Visser, A.W., Pedersen, F.B., 2000. Subsurface phytoplankton blooms fuel 725 pelagic production in the North Sea. Journal of Plankton Research 22, 1663-1671.

726 Romeyn, K., Bouwman, L.A., 1983. Food selection and consumption by estuarine nematodes. 727 Hydrobiological Bulletin 17, 103-109.

728 Rudnick, D.T., 1989. The lags between the deposition and meiobenthic assimilation of 729 phytodetritus. Marine Ecology Progress Series 50, 231-240. 
730

731

732

733

734

735

736

737

738

739

740

741

742

743

744

745

746

747

748

749

750

751

752

753

754

755

756

Schmid-Araya, J.M., Hildrew, A.G., Robertson, A., Schmid, P.E., Winterbottom, J., 2002. The importance of meiofauna in food webs: evidence from an acid stream. Ecology 83, $1271-1285$.

Schratzberger, M., Dinmore, T.A., Jennings, S., 2002. Impacts of trawling on the diversity, biomass and structure of meiofauna assemblages. Marine Biology 140, 83-93.

Schratzberger, M., Warr, K., Rogers, S.I., 2007. Functional diversity of nematode communities in the southwestern North Sea. Marine Environmental Research 63, 368389.

Shannon, C.E., Weaver, W., 1949. The mathematical theory of communication. University of Illinois Press, Urbana, USA, 144 pp.

Soetaert, K., Muthumbi, A., Heip, C., 2002. Size and shape of ocean margin nematodes: morphological diversity and depth-related patterns. Marine Ecology Progress Series 242, 179-193.

Somerfield, P.J., Warwick, R.M., 1996. Meiofauna in marine pollution monitoring programmes. A laboratory manual. Ministry of Agriculture, Fisheries and Food, Directorate of Fisheries Research, Lowestoft, UK, 71 pp.

Stoffels, R.J., Clarke, K.R., Closs, G.P., 2005. Spatial scale and benthic community organisation in the littoral zones of large oligotrophic lakes: potential for cross-scale interactions. Freshwater Biology 50, 1131-1145.

Tett, P., 1987. Plankton, in: Baker, J.M., Wolff, W.M. (Eds.), Biological surveys of estuaries and coasts. Cambridge University Press, Cambridge, UK, pp. 280-341.

Udalov, A.A., Azovsky, A.I., Mokievsky, V.O., 2005. Depth-related pattern in nematode size: what does the depth itself really mean? Progress in Oceanography 67, 1-23.

Vanaverbeke, J., Steyaert, M., Soetaert, K., Rousseau, V., van Gansbeke, D., Parent, J.-Y., Vincx, M., 2004a. Changes in structural and functional diversity of nematode communities during a spring phytoplankton bloom in the southern North Sea. Journal of Sea Research 52, 281-292. 
757

758

759

760

761

762

763

764

765

766

767

Vanaverbeke, J., Soetaert, K., Vincx, M., 2004b. Changes in morphometric characteristics of nematode communities during a spring phytoplankton bloom deposition. Marine Ecology Progress Series 273, 139-146.

Walker, B., Kinzig, A., Landridge, J., 1999. Plant attribute diversity, resilience, and ecosystem function: the nature and significance of dominant and minor species. Ecosystems 2, 95-113.

Warwick, R.M., Price, R., 1979. Ecological and metabolic studies on free-living nematodes from an estuarine mud-flat. Estuarine and Coastal Marine Science 9, 257-271.

Warwick, R.M., Platt, H.M., Somerfield, P.J., 1998. Free-living marine nematodes. Part III. British monohysterids. Field Studies Council, Shrewsbury, UK, 296 pp.

Warwick, R.M., Clarke, K.R., 2001. Practical measures of marine biodiversity based on relatedness of species. Oceanography and Marine Biology: an Annual Review 39, $207-$ 231.

Whitlatch, R.B., 1981. Animal-sediment relationships in intertidal marine benthic habitats: some determinants of deposit-feeding species diversity. Journal of Experimental Marine Biology and Ecology 53, 31-45.

Wieser, W., 1953. Die Beziehung zwischen Mundhöhlengestalt, Ernährungsweise und Vorkommen bei freilebenden marinen Nematoden. Arkiv för Zoologi 4, 439-484. 


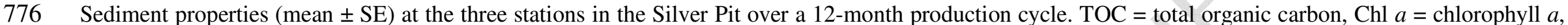

$777 \quad$ Phaeo $=$ phaeopigment

\begin{tabular}{|c|c|c|c|c|c|c|c|}
\hline Station & Date & Grain size $[\mu \mathrm{m}]$ & Silt-clay [\%] & TOC [\%] & $\mathrm{Chl} a\left[\mathrm{mg} \mathrm{m}^{-2}\right]$ & Phaeo $\left[\mathrm{mg} \mathrm{m}^{-2}\right]$ & Chl $a$ :Phaeo \\
\hline \multirow[t]{6}{*}{ A } & 21 - 26 May 2005 & 106 & 21 & 0.38 & $89 \pm 16$ & $111 \pm 40$ & $1.2 \pm 0.5$ \\
\hline & $12-16$ Jul 2005 & 98 & 24 & 0.49 & $21 \pm 10$ & $46 \pm 2$ & $0.5 \pm 0.2$ \\
\hline & 29 Sep - 4 Oct 2005 & 99 & 26 & 0.56 & $31 \pm 7$ & $73 \pm 3$ & $0.4 \pm 0.1$ \\
\hline & $5-10$ Nov 2005 & 104 & 22 & 0.44 & $7 \pm 1$ & $22 \pm 2$ & $0.3 \pm 0.1$ \\
\hline & $13-17$ Feb 2006 & 86 & 28 & 0.51 & $21 \pm 2$ & $51 \pm 8$ & $0.5 \pm 0.1$ \\
\hline & 26 Apr - 5 May 2006 & 84 & 29 & 0.20 & $16 \pm 5$ & $67 \pm 13$ & $0.2 \pm 0.1$ \\
\hline \multirow[t]{6}{*}{$\mathrm{B}$} & 21 - 26 May 2005 & 99 & 21 & 0.31 & $26 \pm 4$ & $113 \pm 10$ & $0.2 \pm 0.1$ \\
\hline & $12-16$ Jul 2005 & 83 & 29 & 0.36 & $9 \pm 4$ & $25 \pm 8$ & $0.3 \pm 0.1$ \\
\hline & 29 Sep -4 Oct 2005 & 85 & 28 & 0.39 & $29 \pm 4$ & $67 \pm 13$ & $0.5 \pm 0.1$ \\
\hline & 5 - 10 Nov 2005 & 90 & 26 & 0.36 & $8 \pm 1$ & $29 \pm 2$ & $0.3 \pm 0.1$ \\
\hline & $13-17$ Feb 2006 & 92 & 22 & 0.33 & $12 \pm 1$ & $46 \pm 2$ & $0.3 \pm 0.0$ \\
\hline & 26 Apr - 5 May 2006 & 97 & 24 & 0.33 & $12 \pm 3$ & $53 \pm 4$ & $0.2 \pm 0.0$ \\
\hline \multirow[t]{6}{*}{$\mathrm{C}$} & $21-26$ May 2005 & 71 & 26 & 0.47 & $72 \pm 38$ & $54 \pm 27$ & $2.5 \pm 1.6$ \\
\hline & $12-16$ Jul 2005 & 78 & 25 & 0.34 & $11 \pm 1$ & $37 \pm 6$ & $0.3 \pm 0.0$ \\
\hline & 29 Sep -4 Oct 2005 & 69 & 28 & 0.34 & $18 \pm 6$ & $54 \pm 4$ & $0.3 \pm 0.1$ \\
\hline & 5 - 10 Nov 2005 & 67 & 29 & 0.35 & $11 \pm 1$ & $25 \pm 3$ & $0.4 \pm 0.0$ \\
\hline & 13 - 17 Feb 2006 & 73 & 24 & 0.44 & $6 \pm 1$ & $32 \pm 2$ & $0.2 \pm 0.0$ \\
\hline & 26 Apr - 5 May 2006 & 74 & 25 & 0.33 & $8 \pm 3$ & $42 \pm 20$ & $0.2 \pm 0.1$ \\
\hline
\end{tabular}


779 Table 2

780 Results from Kruskal-Wallis one-way analysis by ranks: Spatio-temporal differences in 781 sediment properties

\begin{tabular}{lcc}
\hline Source & Test statistic & $p$-value \\
\hline Grain size & & \\
Station & 11.94 & 0.003 \\
Month & 1.09 & 0.950 \\
\hline Silt-clay & & \\
Station & 0.92 & 0.630 \\
Month & 4.13 & 0.530 \\
\hline Total organic carbon & & \\
Station & 3.82 & 0.148 \\
Month & 5.88 & 0.318 \\
Chlorophyll $a$ & & \\
Station & 3.43 & 0.180 \\
Month & 27.41 & $<0.001$ \\
\hline Phaeopigment & & \\
Station & 4.95 & 0.084 \\
Month & 25.80 & $<0.001$ \\
\hline Chlorophyll $a:$ Phaeopigment & & \\
Station & 2.53 & 0.282 \\
Month & 8.72 & 0.121 \\
\hline
\end{tabular}


783 Table 3

784 Results from two-way analysis of variance (ANOVA): Spatio-temporal differences in

785 nematode community-related measures and the relative abundance of discriminating species

\begin{tabular}{|c|c|c|c|c|c|}
\hline Source & $\begin{array}{l}\text { Sum of } \\
\text { squares }\end{array}$ & Df & $\begin{array}{l}\text { Mean } \\
\text { square }\end{array}$ & F-Ratio & $p$-value \\
\hline \multicolumn{6}{|c|}{ Total abundance (Log) } \\
\hline Station & 0.2681 & 2 & 0.1341 & 8.90 & 0.001 \\
\hline Month & 0.1532 & 5 & 0.0306 & 2.03 & 0.088 \\
\hline Station x Month & 0.1523 & 10 & 0.0152 & 1.01 & 0.446 \\
\hline \multicolumn{6}{|c|}{ Species diversity $\left(\mathrm{H}^{\prime}\right)$} \\
\hline Station & 2.9267 & 2 & 1.4634 & 40.36 & $<0.001$ \\
\hline Month & 0.1543 & 5 & 0.0309 & 0.85 & 0.520 \\
\hline Station x Month & 0.4608 & 10 & 0.0461 & 0.05 & 0.270 \\
\hline \multicolumn{6}{|c|}{ Trophic diversity (ITD) } \\
\hline Station & 0.0627 & 2 & 0.0331 & 90.93 & $<0.001$ \\
\hline Month & 0.0034 & 5 & 0.0008 & 2.28 & 0.059 \\
\hline Station x Month & 0.0084 & 10 & 0.0084 & 2.42 & 0.018 \\
\hline \multicolumn{6}{|c|}{ Spilophorella paradoxa [\%] } \\
\hline Station & 8.7173 & 2 & 4.3587 & 1.41 & 0.253 \\
\hline Month & 47.5376 & 5 & 9.5075 & 3.08 & 0.016 \\
\hline Station x Month & 38.3231 & 10 & 3.8323 & 1.24 & 0.288 \\
\hline \multicolumn{6}{|c|}{ Sabatieria punctata [\%] } \\
\hline Station & 406.4300 & 2 & 203.2150 & 8.97 & $<0.001$ \\
\hline Month & 121.2810 & 5 & 24.2562 & 1.07 & 0.387 \\
\hline Station x Month & 256.3180 & 10 & 25.6318 & 1.13 & 0.357 \\
\hline \multicolumn{6}{|c|}{ Leptolaimus elegans [\%] } \\
\hline Station & 452.2720 & 2 & 226.1360 & 33.76 & $<0.001$ \\
\hline Month & 150.2450 & 5 & 30.0491 & 4.49 & 0.002 \\
\hline Station $\mathrm{x}$ Month & 137.5660 & 10 & 13.7566 & 2.05 & 0.045 \\
\hline
\end{tabular}

786 
787 Table 4

788 Mean ( \pm SE) relative abundance of nematode feeding types (sensu Wieser, 1953) at the three

789 stations in the Silver Pit over a 12-month production cycle

\begin{tabular}{|c|c|c|c|c|c|}
\hline Station & Date & $\begin{array}{c}\text { Selective } \\
\text { deposit } \\
\text { feeders [\%] }\end{array}$ & $\begin{array}{c}\text { Non- } \\
\text { selective } \\
\text { deposit } \\
\text { feeders [\%] }\end{array}$ & $\begin{array}{l}\text { Epigrowth } \\
\text { feeders [\%] }\end{array}$ & $\begin{array}{c}\text { Predators } \\
{[\%]}\end{array}$ \\
\hline \multirow[t]{6}{*}{ A } & 21 - 26 May 2005 & $21 \pm 1$ & $43 \pm 1$ & $29 \pm 1$ & $6 \pm 0$ \\
\hline & $12-16$ Jul 2005 & $18 \pm 1$ & $38 \pm 2$ & $37 \pm 3$ & $7 \pm 1$ \\
\hline & 29 Sep - 4 Oct 2005 & $22 \pm 1$ & $42 \pm 2$ & $31 \pm 0$ & $5 \pm 1$ \\
\hline & $5-10$ Nov 2005 & $29 \pm 2$ & $37 \pm 1$ & $28 \pm 4$ & $7 \pm 2$ \\
\hline & $13-17$ Feb 2006 & $24 \pm 1$ & $42 \pm 2$ & $28 \pm 2$ & $6 \pm 1$ \\
\hline & 26 Apr - 5 May 2006 & $20 \pm 2$ & $41 \pm 2$ & $32 \pm 1$ & $7 \pm 1$ \\
\hline \multirow[t]{6}{*}{ B } & $21-26$ May 2005 & $17 \pm 2$ & $35 \pm 4$ & $40 \pm 5$ & $8 \pm 1$ \\
\hline & $12-16$ Jul 2005 & $15 \pm 2$ & $35 \pm 1$ & $46 \pm 2$ & $5 \pm 1$ \\
\hline & $29 \mathrm{Sep}-4$ Oct 2005 & $18 \pm 2$ & $37 \pm 6$ & $42 \pm 5$ & $4 \pm 0$ \\
\hline & $5-10$ Nov 2005 & $15 \pm 2$ & $44 \pm 1$ & $36 \pm 3$ & $5 \pm 1$ \\
\hline & $13-17$ Feb 2006 & $17 \pm 1$ & $34 \pm 3$ & $44 \pm 3$ & $5 \pm 1$ \\
\hline & 26 Apr - 5 May 2006 & $18 \pm 1$ & $33 \pm 3$ & $45 \pm 4$ & $4 \pm 1$ \\
\hline \multirow[t]{6}{*}{$\mathrm{C}$} & $21-26$ May 2005 & $8 \pm 2$ & $44 \pm 4$ & $45 \pm 4$ & $2 \pm 1$ \\
\hline & $12-16$ Jul 2005 & $10 \pm 1$ & $46 \pm 2$ & $42 \pm 3$ & $2 \pm 0$ \\
\hline & $29 \mathrm{Sep}-4$ Oct 2005 & $11 \pm 1$ & $43 \pm 4$ & $44 \pm 4$ & $2 \pm 1$ \\
\hline & $5-10$ Nov 2005 & $11 \pm 0$ & $39 \pm 4$ & $45 \pm 4$ & $5 \pm 0$ \\
\hline & $13-17$ Feb 2006 & $15 \pm 3$ & $40 \pm 4$ & $40 \pm 2$ & $5 \pm 1$ \\
\hline & 26 Apr - 5 May 2006 & $11 \pm 2$ & $41 \pm 5$ & $42 \pm 5$ & $6 \pm 1$ \\
\hline
\end{tabular}


791 Table 5

792 Results from two-way analysis of variance (ANOVA): Spatio-temporal differences in average

793 individual body mass in the total nematode community and for populations of discriminating

794 species

\begin{tabular}{lccccc}
\hline Source & $\begin{array}{c}\text { Sum of } \\
\text { squares }\end{array}$ & Df & Mean square & F-Ratio & $p$-value \\
\hline Total community & & & & & \\
Station & 0.280737 & 2 & 0.140369 & 3.45 & 0.043 \\
Month & 0.320326 & 5 & 0.0640652 & 1.57 & 0.193 \\
Station x Month & 0.490307 & 10 & 0.0490307 & 1.2 & 0.321 \\
\hline Spilophorella paradoxa & & & & & \\
Station & 0.322737 & 2 & 0.161369 & 4.15 & 0.024 \\
Month & 0.481504 & 5 & 0.0963007 & 2.48 & 0.050 \\
Station x Month & 0.339041 & 10 & 0.0339041 & 0.87 & 0.566 \\
\hline Sabatieria punctata & & & & & \\
Station & 0.271078 & 2 & 0.135539 & 4.23 & 0.022 \\
Month & 0.105911 & 5 & 0.0211822 & 0.66 & 0.656 \\
Station x Month & 0.316011 & 10 & 0.0316011 & 0.99 & 0.473 \\
\hline Leptolaimus elegans & & & & & \\
Station & 0.00149259 & 2 & 0.000746296 & 0.41 & 0.667 \\
Month & 0.0101259 & 5 & 0.00202519 & 1.11 & 0.372 \\
Station x Month & 0.0280407 & 10 & 0.00280407 & 1.54 & 0.166 \\
\hline
\end{tabular}


796 Table 6

797 Results from two-way crossed analysis of similarities (ANOSIM): Spatio-temporal

798 differences in the size distribution of the total nematode community and populations of

799 discriminating species

\begin{tabular}{lcccc}
\hline & \multicolumn{2}{c}{ Station } & \multicolumn{2}{c}{ Month } \\
\hline & Spearman R & $p$-value & Spearman R & $p$-value \\
Total community & 0.111 & 0.074 & 0.123 & 0.032 \\
Spilophorella paradoxa & 0.159 & 0.009 & 0.282 & 0.001 \\
Sabatieria punctata & 0.126 & 0.060 & 0.033 & 0.312 \\
Leptolaimus elegans & 0.050 & 0.221 & 0.001 & 0.471 \\
\hline
\end{tabular}

800 
801

802

803

804

805

806

807

808

809

810

811

812

813

814

815

816

817

818

821

824

825

\section{Figure captions}

Fig. 1. Sampling stations in the Silver Pit (A, B and C), with background showing the mean monthly water chlorophyll $a$ concentration for April 2005. The $25 \mathrm{~m}$ depth contour is shown as a solid white line, and the $50 \mathrm{~m}$ contour as a solid black line.

Fig 2. Temporal changes in the mean $( \pm \mathrm{SE})$ sediment chlorophyll $a$ and phaeopigment concentrations across the three stations in the Silver Pit.

Fig. 3. Comparison of mean pelagic and benthic chlorophyll $a$ concentrations in each of the sampling months during 2005 and 2006 coded by sampling station. Shaded areas identify the spring bloom period showing the gradient in pelagic primary production throughout the Silver Pit from west (station A) to east (station C).

Fig 4. Temporal changes in the mean $( \pm \mathrm{SE})$ relative abundance of Spilophorella paradoxa across the three stations in the Silver Pit.

Fig. 5. Non-metric multi-dimensional scaling (MDS) ordination of mean relative abundance of nematode species and feeding types (sensu Wieser 1953) at the three stations in the Silver Pit over a 12-month production cycle. Day of year in parentheses.

Fig. 6. Temporal changes in the mean ( \pm SE) individual body mass of Spilophorella paradoxa across the three stations in the Silver Pit.

Fig. 7. Spatial differences in the mean $( \pm$ SE) absolute abundance of Spilophorella paradoxa over a 12-month production cycle plotted against geometric size class.

827 
828 Fig. 8. Temporal changes in the mean ( \pm SE) absolute abundance of Spilophorella paradoxa

829 in geometric size class -4 to class 0 across the three stations in the Silver Pit. 
Fig. 1

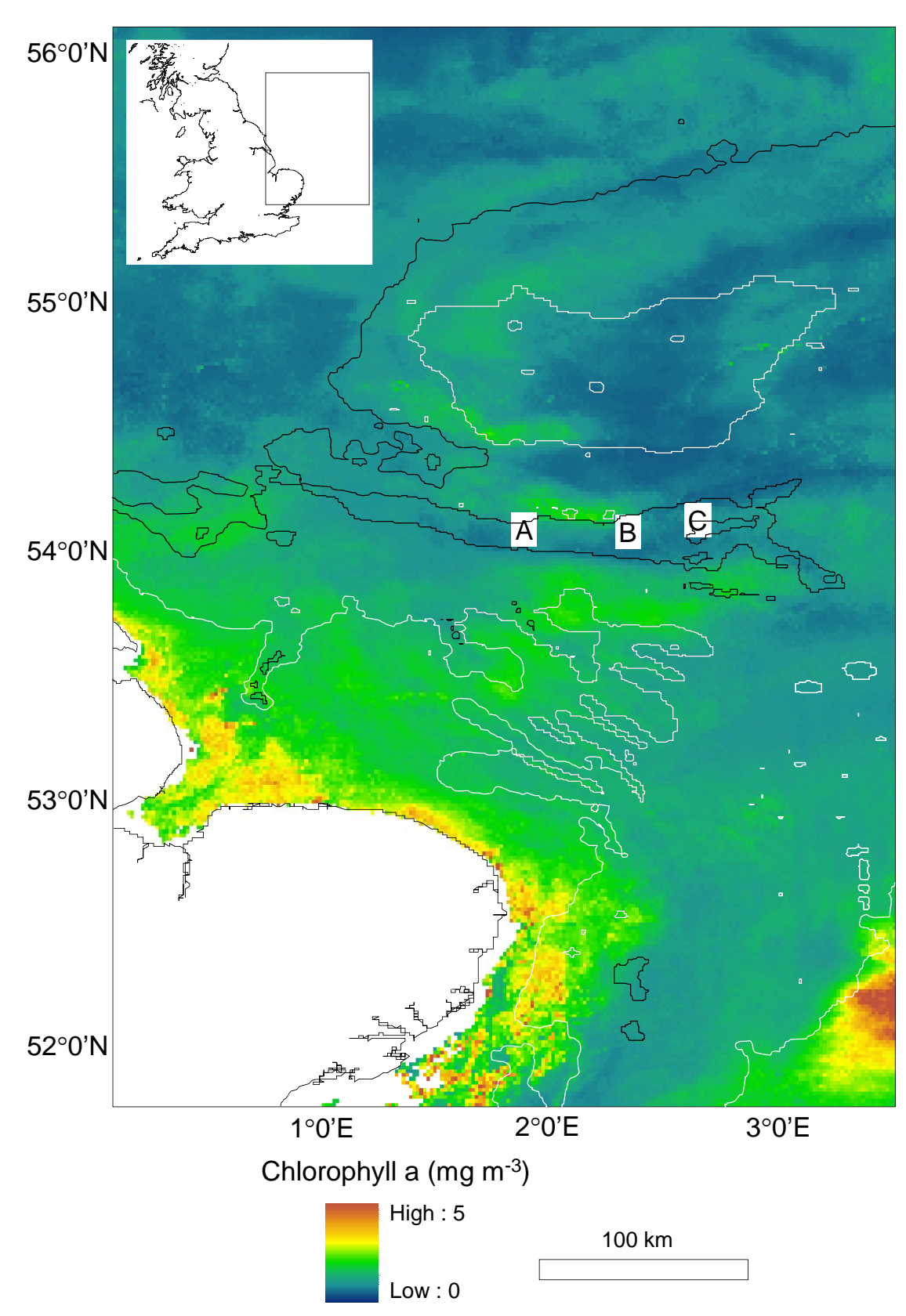


Fig. 2
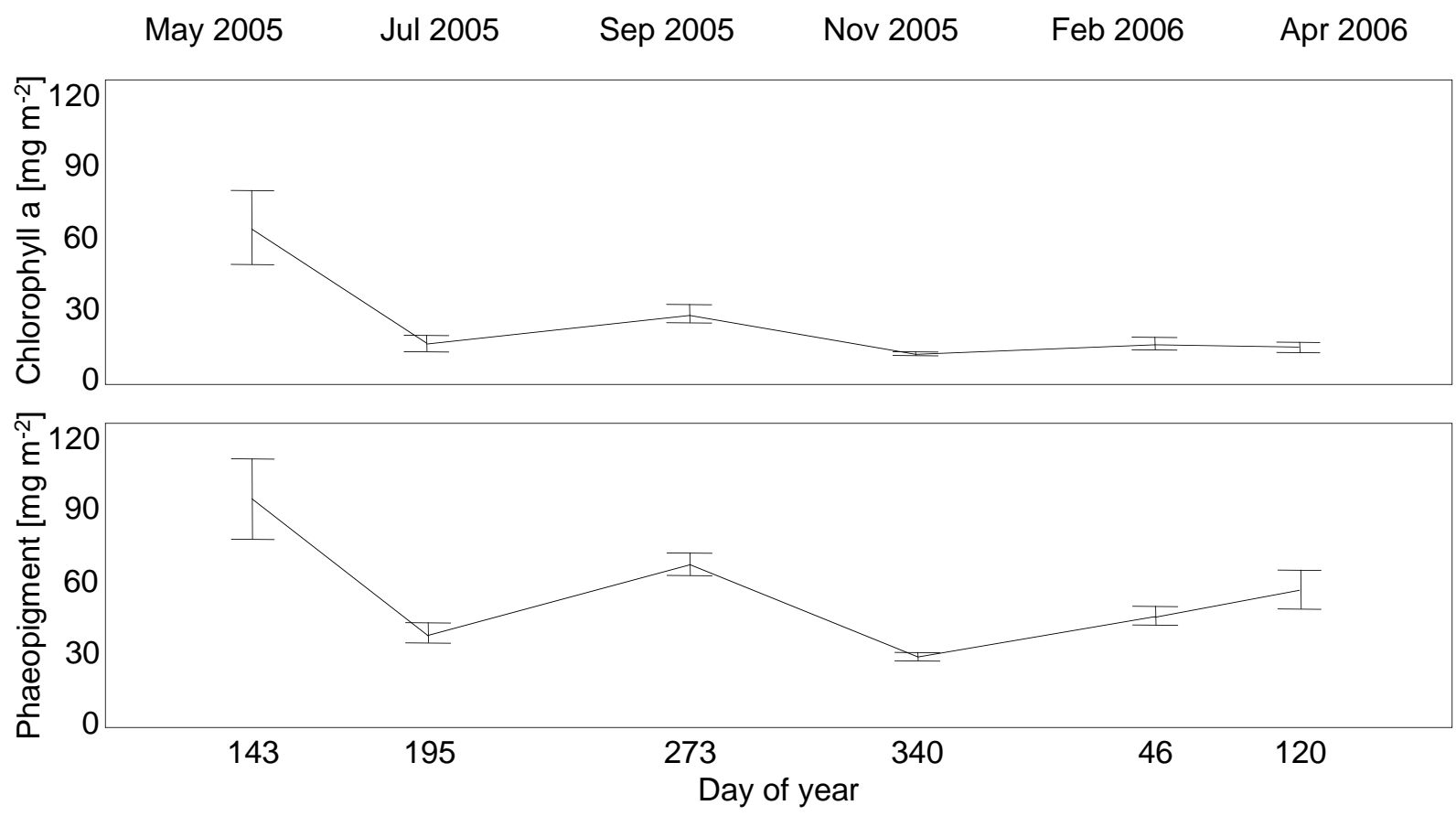
Fig. 3

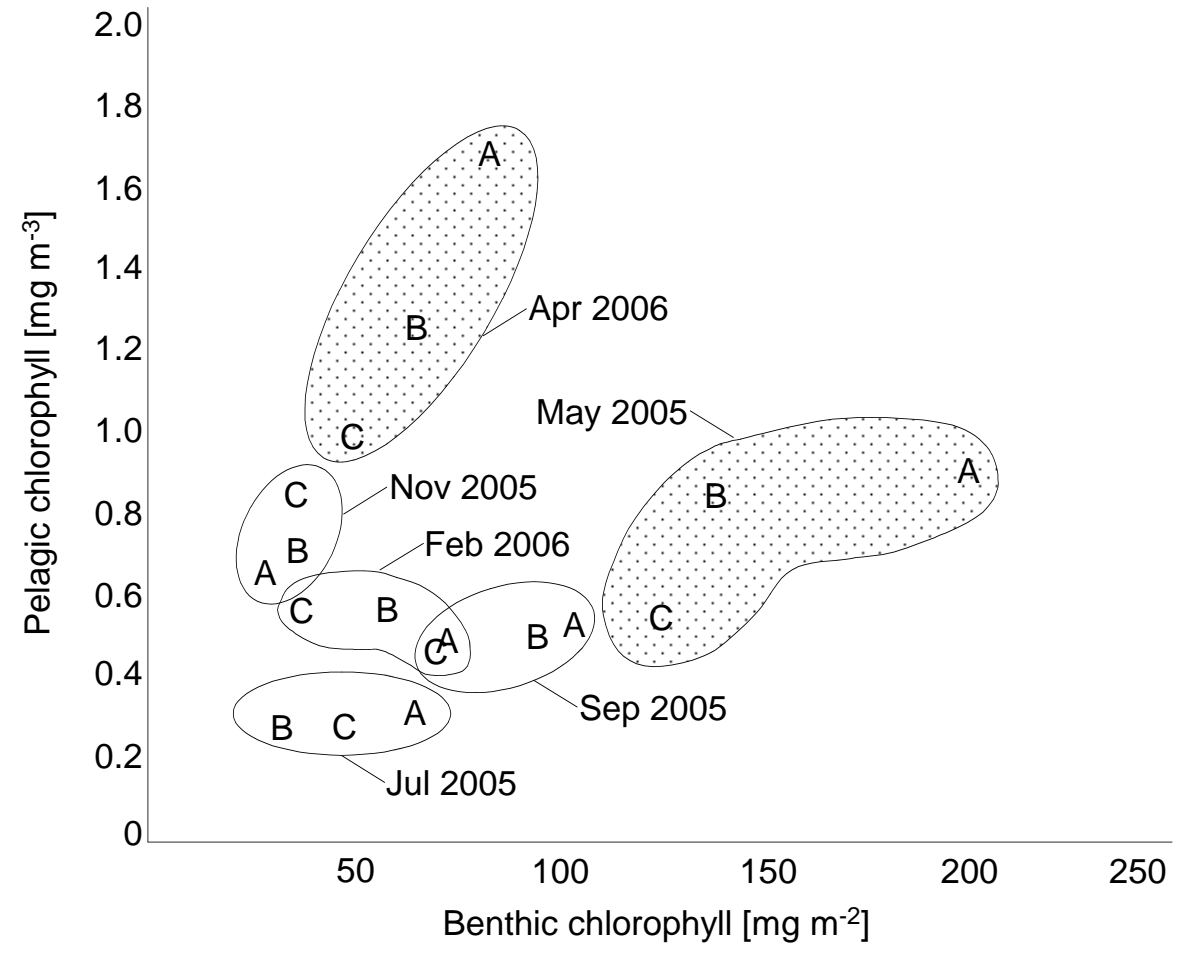


Fig. 4

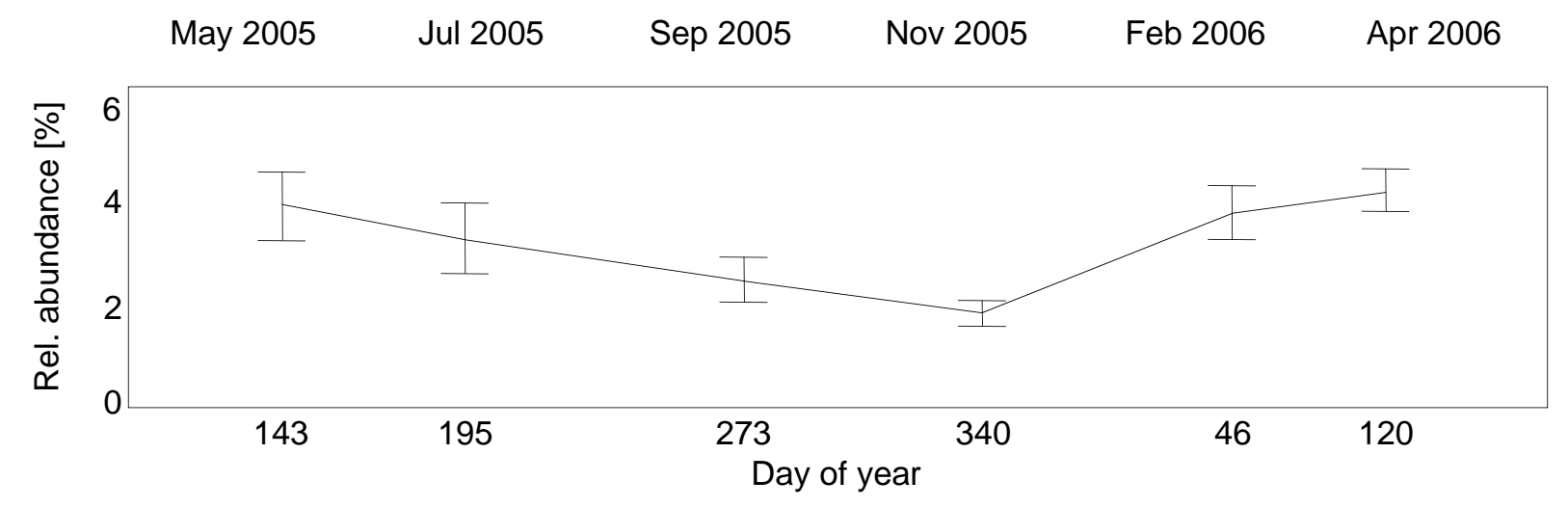


Fig. 5
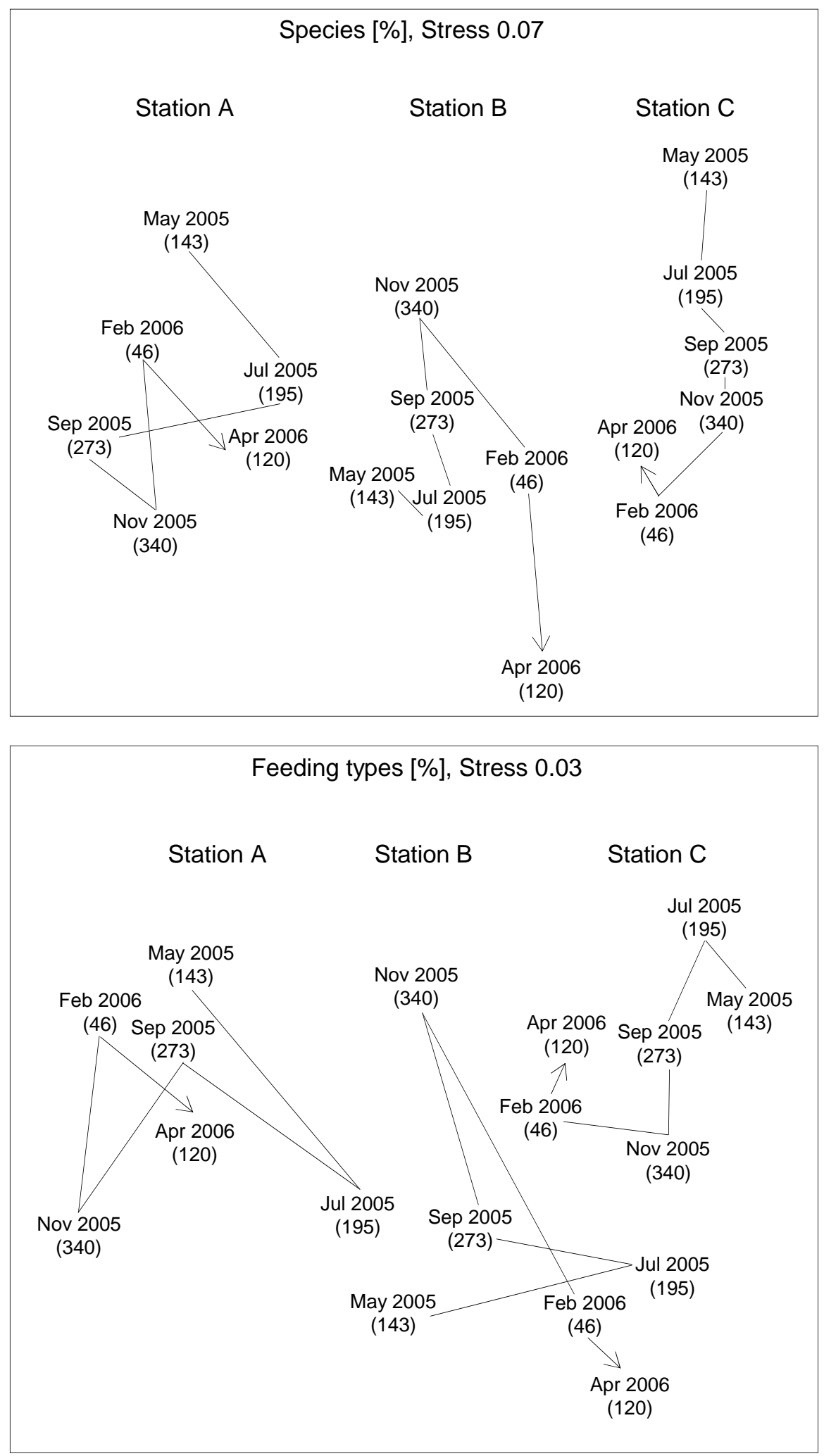
Fig. 6

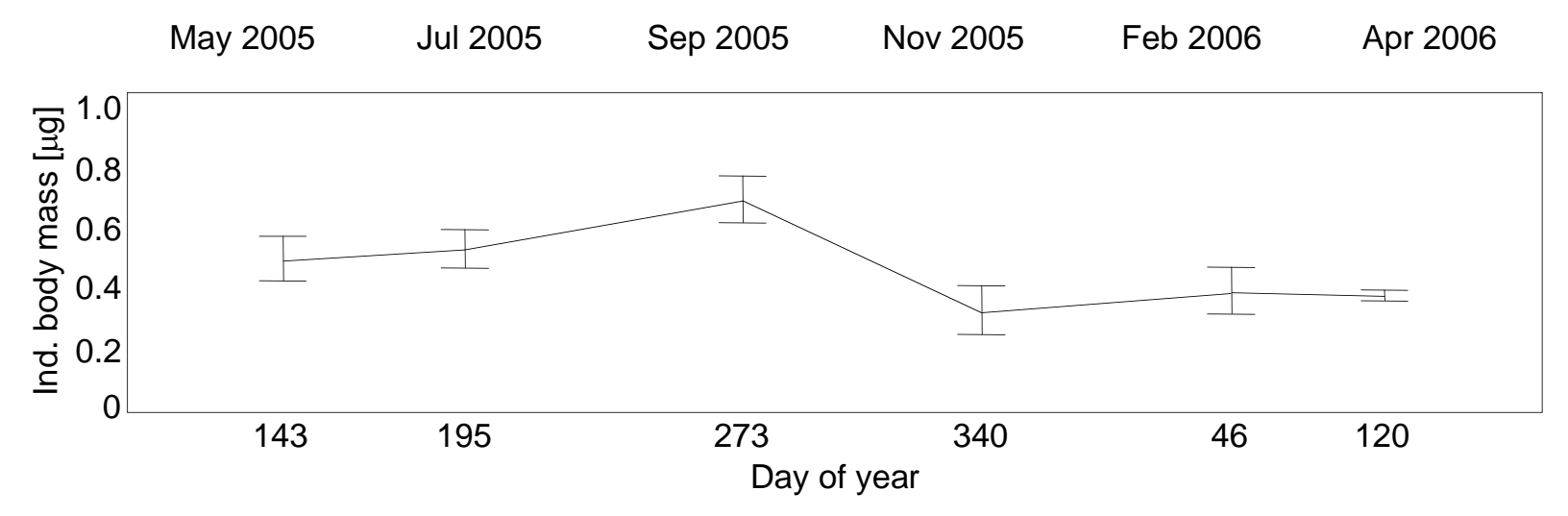


Fig. 7
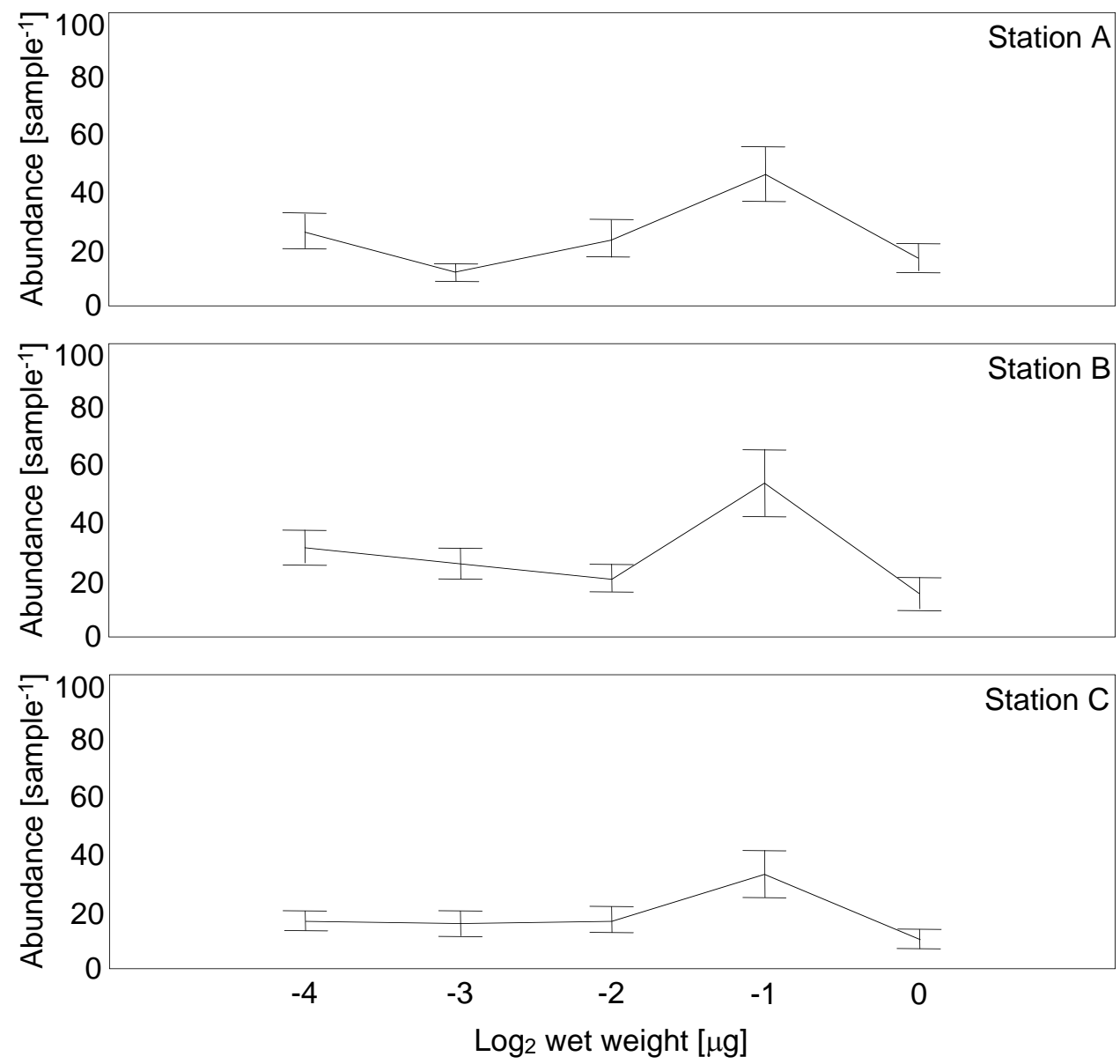
Fig. 8
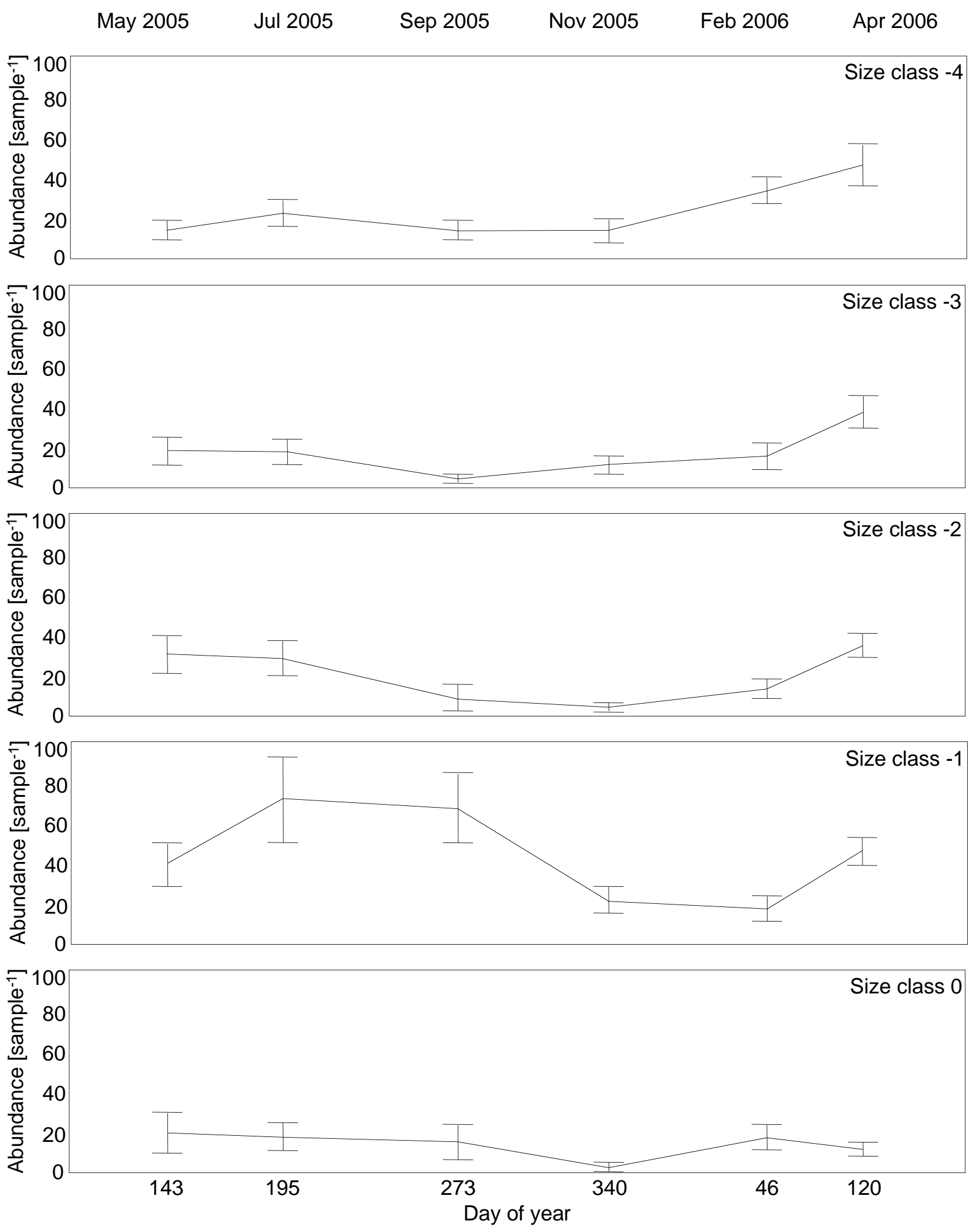